\title{
EDUKASI DAN PENDAMPINGAN PRAKTIKUM FISIKA PADA SISWA SEKOLAH MENENGAH ATAS NEGERI 1 SURALAGA KECAMATAN SURALAGA
}

\author{
Sapiruddin ${ }^{1)}$, Bq. Aryani Novianti ${ }^{1}$, Kertanah ${ }^{1)}$ \\ 1)Program Studi Pendidikan Fisika, Fakultas MIPA, Universitas Hamzanwadi, Selong, NTB, Indonesia \\ Corresponding author : Zafir.Addin@yahoo.com \\ E-mail : Zafir.Addin@yahoo.com
}

Diterima 07 November 2021, Direvisi 03 Desember 2021, Disetujui 03 Desember 2021

\begin{abstract}
ABSTRAK
Fisika merupakan salah satu ilmu pengetahuan alam (IPA) yang tidak hanya memahami secara teori, namun dibutuhkan pemahaman secara praktis juga. Praktikum adalah salah satu cara untuk dapat memberikan pemahaman secara praktis kepada siswa. Tujuan kegiatan adalah memberikan edukasi dan pendampingan praktikum kepada siswa untuk meningkatkan pemahaman secara teoritis dan praktis melalui program pengabdian kepada masyarakat (PkM). Kegiatan edukasi dan pendampingan praktikum pada alat ukur fisika menggunakan mistar, jangka sorong, mikrometer sekrup dan multimeter.Siswa memiliki rasa kepuasan dan keterampilan yang tinggi ditunjukkan dengan persentase hasil kuesioner untuk kedua aspek yaitu keterampilan dan kepuasan diatas $50 \%$. Melalui kegiatan edukasi dan pendampingan praktikum dapat meningkatkan keterampilan dan kemampuan siswa khususnya pada alat ukur fisika.
\end{abstract}

Kata kunci: pendidikan; pendampingan; pengabdian masyarakat; fisika.

\begin{abstract}
Physics is one of natural sciences which is not only needed to understand theoretically, but it is needed practical comprehension. Lab work is a practical way giving comprehension to students. The aim of this study is providing education and assistance in lab work to students for increasing their theoretical and practical comprehension through dedication to community $(\mathrm{PkM})$. In this study focuses on measuring tools of physiscs, such as ruler, calipers, screw micrometer, and multimeter. The students have great satisfaction and skill which have been showed with percentage of questionnaire result in the both aspects, more than fifty percents. Through education and assistance have been able to improve the students' skill and ability, particularly in physics measuring tools.
\end{abstract}

Keywords: education; assistance; dedication to community; physics.

\section{PENDAHULUAN}

Dalam pembelajaran sains, terutama pembelajaran fisika, proses membangun pengetahuan sendiri bagi peserta didik sangatlah penting. Peserta didik hanya akan mengerti dengan sungguh-sungguh dan mempunyai kompetisi dalam bidang fisika yang digeluti bila peserta didik sendiri aktif belajar, mengolah, mencerna, dan merumuskannya dipikirannya sendiri (Suparno, 2013).

Fisika merupakan ilmu yang membahas teori berkaitan dengan gejala alam dan keterkaitannya dengan kenyataan. Fisika merupakan mata pelajaran yang berupaya mendidik siswa bukan hanya memiliki ilmu pengetahuan namun juga memiliki keterampilan yang unggul, fisika melatih melakukan penelitian dan pengamatan sesuai proses ilmiah dengan harapan akan menghasilkan karya ilmiah dan sikap ilmiah yang tinggi. Dengan pernyataan tersebut, maka seharusnya pembelajaran fisika dilakukan tidak hanya dengan bercerita, tetapi dibarengi dengan percobaan yang dapat dilakukan di laboratorium (Amin, 1998).

Praktikum merupakan salah satu metode pembelajaran fisika yang ditempuh oleh guru untuk membantu siswa memahami ilmu fisika. Dalam pelaksanaan praktikum dilaboratorium tidak lepas dari pengamatan (observation) dan percobaan (experimental), dari keduanya sangat berkaitan erat, karena akan berhubungan dengan hasil percobaan yang dilakukan. Pelaksanaan praktikum secara efektif merupakan salah satu syarat dalam pembelajaran fisika (Mahiruddin, 2008). Efektivitas pelaksanaan praktikum dapat dilihat sikap siswa, saat kegiatan akan dimulai, saat praktikum berlangsung hingga praktikum telah selesai. Praktikum Fisika mempunyai beberapa manfaat yang berguna dalam kehidupan siswa. Fisika adalah ilmu yang berdasarkan 
percobaan, sehingga tanpa adanya percobaan akan terasa lebih mudah dalam memahaminya. Sebagai pembentuk sikap ilmiah bagi siswa seperti dimiliki pada para ahli ilmu pengetahuan yang menyelesaikan masalah berdasarkan metode ilmiah.

Dari hasil kunjungan ke sekolah SMAN 1 Suralaga , kabupaten Lombok Timur bahwa dalam pembelajaran fisika, metode pembelajaran dengan praktikum masih kurang diterapkan oleh guru, meskipun pemerintah sudah memfasilitasi pengadaan alat-alat laboratorium. Hal ini karena sebagian guru dan siswa masih kurang menguasai penggunaan alat-alat praktikum. Berdasarkan latar belakang tersebut maka peneliti tertarik untuk melakukan edukasi dan pendampingan praktikum alat ukur fisika siswa di SMAN 1 Suralaga, kabupaten Lombok Timur melalui kegiatan pengabdian kepada masyarakat (PkM).

\section{METODE}

Kegiatan pengabdian kepada masyarakat (PkM) dilaksanakan di SMAN 1 Suralaga. Kegiatan ini dilaksanakan pada bulan November 2021. SMAN 1 Suralaga merupakan salah satu sekolah di kecamatan Suralaga, kabupaten Lombok Timur yang masih belum efektif dalam menerapkan praktikum sebagai proses kegiatan belajar - mengajar (KBM) di kelas. Peserta dalam kegiatan ini adalah siswa kelas XII IPA, satu kelas dengan jumlah siswa 26 orang dengan materi praktikum tentang alat ukur fisika. Metode yang dilaksanakan dalam kegiatan PkM ini yaitu melakukan edukasi dan pendampingan praktikum alat ukur fisika secara langsung di sekolah. Adapun prosedur prosedur yang dilakukan dalam kegiatan edukasi dan pendampingan ini adalah diilustrasikan pada diagram alir dibawah ini.

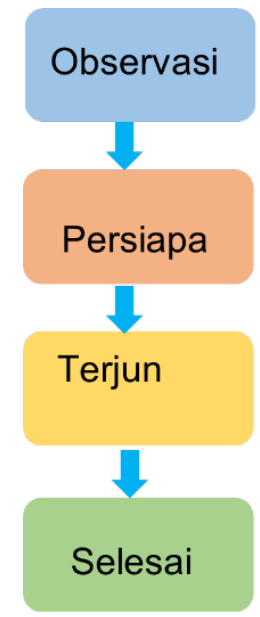

Gambar 1. Diagram alir prosedur kegiatan

Observasi merupakan tahap awal yang dilakukan dalam kegiatan ini. Proses observasi ini dilakukan secara langsung ke sekolah dengan bertemu dan berdiskusi bersama kepala sekolah dan guru matapelajaran dengan tujuan melihat dan mencari informasi bagaimana KBM di sekolah dan kondisi alat alat praktikum khususnya fisika di laboraturium sekolah. Kegiatan persiapan dilakukan dengan tujuan untuk mempersiapkan perlengkapan, akomodasi, dan lainnya yang dibutuhkan untuk melaksanakan kegiatan eduaksi dan pendampingan di sekolah. Berikutnya, terjun ke sekolah langsung untuk melaksanakan edukasi dan pendampingan praktikum alat fisika untuk memberikan pengetahuan, meningkatkan kemampuan dalam memahami alat - alat praktikum fisika baik secara teori maupun secara praktis (praktikum). Setelah kegiatan edukasi dan pendampingan selesai, dilakukan penutupan dan melakukan pembuatan laporan.

\section{HASIL DAN PEMBAHASAN Kegiatan Edukasi}

Pengertian edukasi menurut Langeveld (Kusniyati \& Sitanggang, 2016) merupakan proses pembelajaran yang bertujuan untuk mengembangkan potensi peserta didik dan mewujudkan proses pembelajaran yang lebih baik. Sebelum kegiatan pendampingan praktikum alat fisika dilaksanakan, ditahap awal dilakukan penyampaian materi tentang alat ukur fisika seperti ditujnjukkan pada Gambar 2.

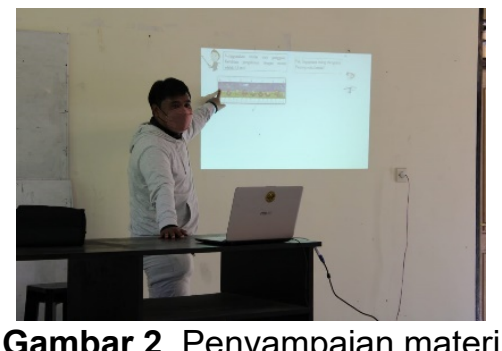

Gambar 2. Penyampaian materi

Pemberian materi pada Gambar 2 merupakan kegiatan awal sebagai edukasi untuk memberikan tambahan pengetahuan dan pemahaman kembali tentang cara menggunakan alat ukur, fungsi beserta cara membaca alat dari hasil pengukuran sebelum melakukan kegiatan pendampingan praktikum. Menurut Suriasuman (Sakti, 2011), pengetahuan adalah segala apa yang diketahui manusia tentang sesuatu objek tertentu termasuk didalamnya ilmu yang akan memperkaya khasanah mentalnya baik secara langsung maupun tidak langsung.

\section{Kegiatan Pendampingan}

Pada tahap kegiatan pendampingan ini, siswa dibagi menjadi beberapa kelompok dengan masing - masing kelompok memiliki 1 orang mentor atau asisten yang membantu 
menjelaskan serta mendampingi mereka melakukan kegiatan demonstrasii alat dan praktikum.

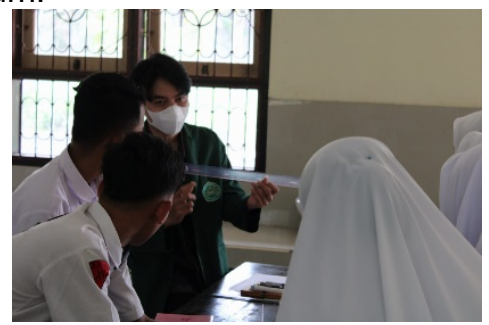

a)

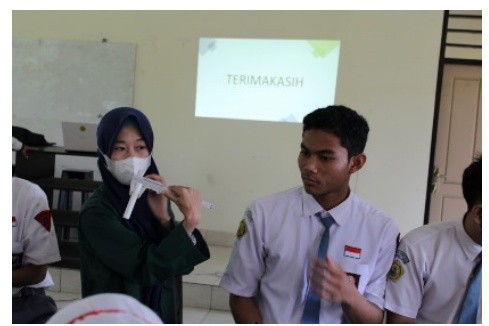

b)

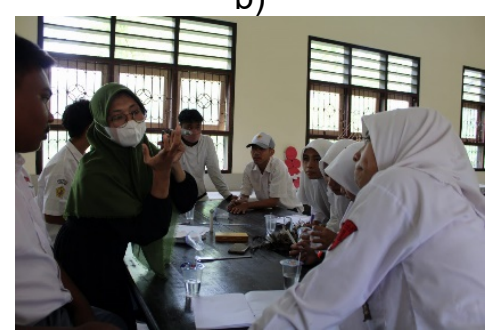

c)

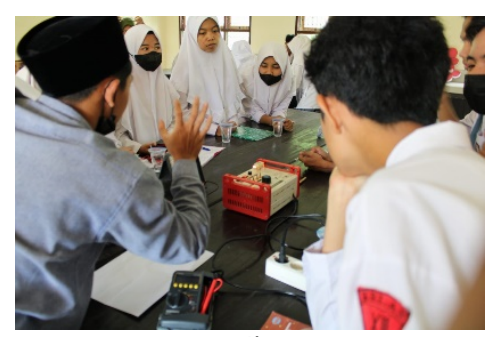

d)

Gambar 3. Pendampingan alat ukur a) Mistar; b) Jangka sorong; c) Mikrometer sekrup; d) Multimeter

Kegiatan pendampingan praktikum alat ukur fisika sperti yang direpresentasikan pada Gambar 3 a), b), c), dan d) yaitu merupakan kegiatan inti dari rangkaiaan kegiatan program pengabdian kepada masyarakat ( $\mathrm{PkM})$ yang dilaksanakan di sekolah SMAN 1 Suralaga. Para pendamping menjelaskan dari masing masing alat ukur fisika mulai dari bagian bagian alat, cara menggunakan, melakukan demonstrasi percobaan penggunaan alat ukur secara langsung serta cara membaca hasil pengukuran seperti mengukur panjang papan dengan mistar, mengukur diameter luar dan kedalaman tabung menggunakan jangka sorong, mengukur ketebalan dan diameter logam menggunakan mikrometer sekrup, dan mengukur kuat arus, tegangan listrik menggunakan multimeter.

Di dalam kegiatan edukasi dan pendampingan praktikum ada dua hal yang telah diobservasi yaitu keterampilan dan kepuasan, secara berurutan. Keterampilan menurut Devi (Suryaningsih, 2017) mengacu pada kemampuan untuk menggunakan pikiran, penalaran, dan tindakan seseorang secara efisien dan efektif untuk mencapai hasil tertentu, termasuk kreativitas.

Tabel 1. Tabel Hasil Angket Keterampilan.

\begin{tabular}{|c|c|c|c|}
\hline \multirow[b]{2}{*}{ Soal } & \multicolumn{3}{|c|}{ Jawaban } \\
\hline & $\begin{array}{l}\text { Sangat } \\
\text { Setuju } \\
(\%)\end{array}$ & $\begin{array}{l}\text { Setuju } \\
(\%)\end{array}$ & $\begin{array}{l}\text { Tidak } \\
\text { Setuju } \\
(\%)\end{array}$ \\
\hline $\begin{array}{l}\text { 1. Saya bisa } \\
\text { menggunakan } \\
\text { alat ukur }\end{array}$ & 30,77 & 69,23 & 0 \\
\hline $\begin{array}{l}\text { 2. Saya dapat } \\
\text { memahami cara } \\
\text { penggunaan alat } \\
\text { ukur } \\
\text { penggaris/mistar }\end{array}$ & 53,85 & 46,15 & \\
\hline $\begin{array}{l}\text { 3. Saya dapat } \\
\text { memahami cara } \\
\text { membaca hasil } \\
\text { pengukuran alat } \\
\text { ukur } \\
\text { penggaris/mistar }\end{array}$ & 53,85 & 42,31 & 3,85 \\
\hline $\begin{array}{l}\text { 4. Saya dapat } \\
\text { memahami cara } \\
\text { penggunaan alat } \\
\text { ukur jangka } \\
\text { sorong }\end{array}$ & 42,31 & 57,69 & \\
\hline $\begin{array}{l}\text { 5. Saya dapat } \\
\text { memahami cara } \\
\text { membaca hasil } \\
\text { pengukuran alat } \\
\text { ukur jangka } \\
\text { sorong }\end{array}$ & 46,15 & 53,85 & \\
\hline $\begin{array}{l}\text { 6. Saya dapat } \\
\text { memahami cara } \\
\text { penggunaan alat } \\
\text { ukur mikrometer } \\
\text { sekrup }\end{array}$ & 46,15 & 53,85 & \\
\hline $\begin{array}{l}\text { 7. Saya dapat } \\
\text { memahami cara } \\
\text { membaca hasil } \\
\text { pengukuran alat } \\
\text { ukur mikrometer } \\
\text { sekrup }\end{array}$ & 30,77 & 69,23 & \\
\hline $\begin{array}{l}\text { 8. Saya dapat } \\
\text { memahami cara } \\
\text { penggunaan alat } \\
\text { ukur multitester }\end{array}$ & 38,46 & 46,15 & 15,38 \\
\hline $\begin{array}{l}\text { 9. Saya dapat } \\
\text { memahami cara } \\
\text { membaca hasil } \\
\text { pengukuran alat }\end{array}$ & 23,08 & 61,54 & 15,38 \\
\hline
\end{tabular}




\begin{tabular}{|c|c|c|c|}
\hline ukur multitester & & & \\
\hline $\begin{array}{l}\text { 10. Saya mudah } \\
\text { memahami } \\
\text { bentuk } \\
\text { rangkaian listrik } \\
\text { secara seri }\end{array}$ & 34,62 & 61,54 & 3,85 \\
\hline $\begin{array}{l}\text { 11. Saya mudah } \\
\text { memahami } \\
\text { bentuk } \\
\text { rangkaian listrik } \\
\text { secara paralel }\end{array}$ & 23,08 & 73,07 & 3,85 \\
\hline
\end{tabular}

Tabel 1 merepresentasikan jumlah presentase jawaban kuesioner siswa untuk melihat keterampilan. Data ini diambil setelah melaksanakan kegiatan pendampingan praktikum. Dari hasil yang ditunjukkan pada Tabel 1 diatas memperlihatkan hasil rata-rata yang sebagian besar adalah setuju. Hal tersebut artinya bahwa hampir diatas 50\% siswa sudah memiliki keterampilan yang baik dalam memahami dan menguasai tentang praktikum alat ukur fisika jika dibandingkan sebelum pendampingan dilaksanakan yang ditunjukkan dengan hasil diskusi atau tanya jawab kepada siswa sebelum secara langsung.

Dalam aspek kepuasan telah dilakukan observasi juga setelah kegiatan pendampingan praktikum dengan mengisi kuesioner oleh para siswa. Data hasil kuesioner ditunjukkan pada Tabel 2 di bawah ini.

Tabel 2. Tabel Hasil Angket Kepuasan.

\begin{tabular}{|c|c|c|c|}
\hline \multirow[b]{2}{*}{ Soal } & \multicolumn{3}{|c|}{ Jawaban } \\
\hline & $\begin{array}{l}\text { Sangat } \\
\text { Setuju } \\
(\%)\end{array}$ & $\begin{array}{l}\text { Setuju } \\
(\%)\end{array}$ & $\begin{array}{l}\text { Tidak } \\
\text { Setuj } \\
\text { u (\%) }\end{array}$ \\
\hline $\begin{array}{l}\text { 1. Materi PkM } \\
\text { sesuai dengan } \\
\text { kebutuhan } \\
\text { mitra/peserta }\end{array}$ & 46,15 & 53,84 & 0 \\
\hline $\begin{array}{lr}2 . & \text { Kegiatan } \\
\text { PkM yang } \\
\text { dilaksanakan } \\
\text { sesuai harpan } \\
\text { mitra/peserta }\end{array}$ & 38,46 & 57,69 & 0 \\
\hline $\begin{array}{l}3 . \quad \text { Cara } \\
\text { pemateri } \\
\text { menyajikan } \\
\text { materi menarik }\end{array}$ & 50 & 50 & \\
\hline $\begin{array}{l}\text { 4. Materi yang } \\
\text { disajikan jelas } \\
\text { dan mudah } \\
\text { difahami }\end{array}$ & 46,15 & 50 & 3,85 \\
\hline $\begin{array}{l}\text { 5. Waktu yang } \\
\text { disediakan } \\
\text { sesuai untuk } \\
\text { penyampaian } \\
\text { materi dan } \\
\text { kegiatan PkM }\end{array}$ & 34,62 & 61,54 & 3,85 \\
\hline 6.Peserta/mitr & 26,92 & 73,08 & 0 \\
\hline
\end{tabular}

\begin{tabular}{|c|c|c|c|}
\hline $\begin{array}{l}\text { a berminat } \\
\text { untuk } \\
\text { mengikuti } \\
\text { kegiatan PkM } \\
\text { selama sesuai } \\
\text { dengan } \\
\text { kebutuhan } \\
\text { mitra/peserta }\end{array}$ & & & \\
\hline $\begin{array}{l}7 . \quad \text { Anggota } \\
\text { PkM yang } \\
\text { terlibat dalam } \\
\text { kegiatan } \\
\text { pengabdian } \\
\text { masyarakat } \\
\text { memberikan } \\
\text { pelayanan } \\
\text { sesuai dengan } \\
\text { kebutuhan }\end{array}$ & 30,77 & 65,38 & 3,85 \\
\hline $\begin{array}{l}\text { 8. Kegiatan } \\
\text { PkM dilakukan } \\
\text { secara } \\
\text { berkelanjutan }\end{array}$ & 23,08 & 69,23 & 7,69 \\
\hline $\begin{array}{l}\text { 9.Setiap } \\
\text { keluhan/perta } \\
\text { nyaan/permas } \\
\text { alahan yang } \\
\text { diajukan } \\
\text { ditindaklajuti } \\
\text { dengan baik } \\
\text { oleh } \\
\text { narasumber/a } \\
\text { nggota } \\
\text { pengabdian } \\
\text { yang terlibat }\end{array}$ & 19,23 & 73,08 & 3,85 \\
\hline $\begin{array}{l}10 . \\
\text { Peserta/mitra } \\
\text { mendapatkan } \\
\text { manfaat } \\
\text { langsung dari } \\
\text { kegiatan PkM } \\
\text { yang } \\
\text { dilaksanakan }\end{array}$ & 53,85 & 46,15 & 0 \\
\hline $\begin{array}{l}\text { 11. Kegiatan } \\
\text { PkM berhasil } \\
\text { meningkatkan } \\
\text { kecerdasan } \\
\text { mitra }\end{array}$ & 42,31 & 57,69 & 0 \\
\hline $\begin{array}{l}12 . \quad \text { Secara } \\
\text { umum, } \\
\text { Mitra/peserta } \\
\text { puas terhadap } \\
\text { kegiatan PkM }\end{array}$ & 42,31 & 57,69 & 0 \\
\hline
\end{tabular}

Data hasil kuesioner untuk kepuasan di Tabel 2 di atas memperlihatkan bahwa para siswa puas dengan kegiatan pendampingan praktikum. Menurut Sumarwan (Udiutomo, 2011) menyatakan bahwa kepuasan merupakan tingkat perasaan setelah membandingkan hasil yang dirasakan dengan 
harapannya. Rata-rata hasil kepuasan siswa diatas $50 \%$ yang artinya bahwa sebagian besar siswa memiliki rasa kepuasan yang tinggi dalam kegiatan pendampingan praktikum melalui kegiatan pengabdian kepada masyarakat (PkM).

\section{SIMPULAN DAN SARAN Simpulan}

Kegiatan edukasi dan pendampingan di SMAN 1 Suralaga berjalan dengan baik. Siswa memiliki rasa kepuasan dan keterampilan dengan nilai presentase rata-rata diatas $50 \%$. Hal ini menunjukkan bahwa siswa kelas XII IPA SMAN 1 Suralaga memiliki tingkat kepuasan dan keterampilan yang tinggi secara berurutan. Melalui kegiatan PkM, edukasi dan pendampingan praktikum dapat meningkatkan keterampilan dan pemahaman siswa.

\section{Saran}

Kegiatan seperti memberikan edukasi dan pendampingan ke para siswa-siswi di sekolah sangat baik, perlu dilaksanakan secara kontinyu. Kegiatan seperti ini tidak hanya dilaksanakan pada sekolah-sekolah negeri, tetapi kedepannya dapat juga dilaksanakan disekolah swasta terutama yang masih memiliki keterbatasan sarana prasarana pendukung trutama laboratorium.

\section{UCAPAN TERIMAKASIH}

Untuk Kami mengucapkan terimaksih kepada Universitas Hamzanwadi sudah memberikan dana bantuan dana kegiatan PkM ini, kepala sekolah dan guru matapelajaran fisika SMAN 1 Suralaga atas izin yang diberikan.

\section{DAFTAR RUJUKAN}

Amin, P. G. (1998). Diktat Alat-alat Ukur Fisika. Yogyakarta: IKIP Yogyakarta.

Kusniyati, H., \& Sitanggang, N. S. P. (2016). APLIKASI EDUKASI BUDAYA TOBA SAMOSIR BERBASIS ANDROID. 9(1), 918.

Mahiruddin. (2008). Pengaruh Fasilitas dan Kompetensi Pengelola Terhadap Efektivitas Manajemen Laboratorium IPA SMA Di Kabupaten Konawe. Retrieved April 19, 2021, from http://mardikanyom.tripod.com/ArtikelPdf. pdf

Sakti, I. (2011). Korelasi Pengetahuan Alat Praktikum Fisika Dengan Kemampuan Psikomotorik Siswa Di SMA Negeri q Kota Bengkulu. IX(1), 67-76.

Suparno, P. (2013). Metodologi Pembelajaran Fisika, Konstruktivistik dan Menyenangkan. Yogyakarta: Universitas Sanata Dharma.
Suryaningsih, Y. (2017). Pembelajaran Berbasis Praktikum Sebagai Sarana Siswa Untuk Berlatih Menerapkan Keterampilan Proses Sains Dalam Materi Biologi. 2, 49-57.

Udiutomo, P. (2011). Analisa Tingkat Kepuasan Siswa Terhadap Layanan Program Smart Ekselensia Indonesia Tahun 2011. 1(1). 